\title{
PEMBAGIAN HARTA WARISAN DITINJAU DARI KITAB UNDANG-UNDANG HUKUM PERDATA
}

\author{
Ni Luh Gede Suwarni, I Nyoman Putu Budiartha, Desak Gde Dwi Arini \\ Fakultas Hukum Universitas Warmadewa, Denpasar-Bali, Indonesia
}

\begin{abstract}
Abstrak
Indonesia mengalami perkembangan pesat dari jaman nenek moyang sampai jaman modern dimana masyarakatnya hidup dengan fasilitas yang dapat menunjang kehidupan sehari-hari. Rumusan masalah adalah Bagaimana pembagian harta warisan menurut KUH Perdata, dan bagaimana penyelesaian sengketa terhadap pembagian hasil warisan menurut KUH Perdata? Metode yang digunakan adalah tipe penelitian hukum normatif dengan metode pencatatan dan pengkajian berdasarkan bahan-bahan hokum. Berdasarkan hasil analisis data adapun hasil dalam penelitian ini adalah yang pertama perpindahan hak dan kewajiban ahli waris Menurut bentuknya ada tiga macam testament pembagian harta warisan yaitu: (1) Openbaartestament suatu terstament dibuat oleh seorang notaris Orang yang akan meninggalkan warisan menghadap pada notaris dan menyatakan kehendaknya, (2) Olographis testament harus dituliskan dengan tangan orang yang akan meninggalkan warisan itu sendiri (elgenhading), (3) Testament rahasia juga dibuat sendiri oleh orang yang akan meninggalkan warisan tetapi tidak diharuskan ia menulis dengan tangan sendiri, yang kedua adalah penyelesaian sengketa litigasi ada dua yaitu Pengadilan umum artinya pengadilan negeri berwenang memeriksa sengketa sedangkan pengadilan niaga pengadilan khusus yang berada di lingkungan pengadilan umum yang mempunyai kompetensi untuk memeriksa dan memutuskan permohonan penyertaan dan penundaan kewajiban pembayaran utang (PKPU) dan sengketa HaKI
\end{abstract}

Kata Kunci: Harta Warisan; Kitab Undang-Undang Hukum Perdata

\begin{abstract}
Indonesia has experienced rapid development from ancestral ages to modern ages in terms of its people living with daily-supporting facilities. In other words, the Indonesian people live with a legacy which is then developed. Regarding inheritance, this study examines two legal issues: (1) distribution of inheritance according to the Civil Code and (2) settlement of disputes over distribution of inheritance results according to the Civil Code. This study was designed using a normative legal research method design; the data were collected by applying note-taking and analysing techniques based on legal materials. Based on the results of data analysis, it is found that in terms of its form there are three types of rights and obligations of an heir: openbaar testament, a form of inheritance made by a notary, in which case, the person who will transfer the inheritance appears before a notary and declares his will; olographis testament, a form of inheritance realising in writing by hand and is affixed by the hand of the inheritor (elgenhading / gedepoecerd); and a secret testament, a form of inheritance that requires the transfer of inheritance by written evidence, made by the person transferring the inheritance but not necessarily handwritten. There are two forms of dispute resolution related to inheritance through litigation, namely the general court, which in this case is the district court, the authority to examine disputes and the commercial court of a special court that is within the environment of a general court that has the competence to examine and decide an application for participation and postponement of debt payment obligation (PKPU) and disputes over intellectual property rights (HaKI).
\end{abstract}

Key word: Inheritance; Code of Civil law

\section{PENDAHULUAN}

Indonesia merupakan negara yang mengutamakan kepentingan masyarakatnya perubahan demi perubahan terjadi sejak era nenek moyang sampai era modern namun beberapa hal tidak mengalami perubahan bahkan dari jaman nenek moyang ialah harta warisan merupakan peninggalan dari orang yang sudah meninggal biasanya diberikan atau hibahkan kepada keturunan mereka dengan tujuan agar mengembangkan suatu yang ditinggalnya minimal membuat 
perubahan terhadap kehidupan orang yang mendapat warisan terkadang pembagian harta warisan yang tidak dianggap adil oleh beberapa pihak membuat timbul konflik diantara para pewaris membuat tidak harmonis suatu hubungan keluarga Pemerintah mengantisipasi hal tersebut membuat suatu peraturan dimana seseorang dapat menuntut dan dituntut berkaitan warisan melalui aturan hukum perdata yang berlaku di Indonesia. Hukum waris BW mengenal 3 (tiga) asas, yaitu pertama, asas individual (asas pribadi) dimana yang menjadi ahli waris adalah perorangan, kedua asas bilateral yaitu seseorang tidak hanya mewaris dari bapak saja tetapi juga sebaliknya dari ibu, demikian juga saudara laki-laki mewaris dari saudara laki-lakinya, maupun saudara perempuannya yang ketiga asas asas perderajatan, artinya bahwa ahli waris yang derajatnya dekat dengan si pewaris menutup ahli waris yang lebih jauh derajatnya, maka untuk mempermudah perhitungan diadakan penggolongan-penggolongan ahli waris (Oemar Moechthar, 2017).

Dalam aturan hukum perdata seorang yang dengan sengaja mempergunakan hak waris milik orang lain dapat dituntut dan diadili oleh hukum melalui pengadilan hukum perdata Sistem waris mengutamakan hubungan antar keluarga dimana biasanya seorang mewarisi harta bendanya saat dirinya berada diusia renta atau sudah tidak bisa beraktifitas serta mengetahui kondisi keuangan anak-anaknya membuat seorang memberikan hak miliknya kepada penerusnya (Ramli, 2013). Segala yang diwariskan tidak semata hanya kekayaan atau uang melainkan banyak variasinya semisal sawah perkebunan saham perusahaan dan banyak lagi yang membuat seorang yang mendapat warisan memiliki tanggung jawab besar terhadap warisan yang diterima Menjadi seorang yang mewarisi milik keluarga sebelumnya senantiasa menjaga dan merawat bahkan sampai mengembangkan demi menunjang perekonomian keluarga dimasa mandatang (Ali, 2000). Dukungan keluarga pewaris sangat berarti mengingat bertambahnya tanggung jawab seorang pewaris selain membiayai keluarganya keuntungan mendapat warisan tergantung daripada apa yang diwariskan semisal mendapat hak atas sawah keuntungannya dapat ditanami berbagai macam kebutuhan pokok atau jika dalam keadaan sulit dapat dijual demi melangsungkan hidup.

Membahas warisan tidak akan ada habisnya terdapat konflik saat ada salah satu pihak merasa tidak adil dalam pembagian harta warisan keharmonisan keluarga dipertaruhkan jika terjadi konflik Mediasi diperlukan antar keluarga jika terjadi hal tersebut guna mencari titik tengah dari permasalahan yang dihadapi. Dalam hukum perdata tidak semua harta warisan dapat dimiliki seutuhnya artinya segala suatu yang diberikan namun terdapat amanat didalamnya merupakan tanggung jawab merawat dan menjaga warisan tersebut semisal seorang ayah memberikan warisan berupa lahan kelapa sawit kepada kedua anaknya dengan pembagian sama namun terdapat amanat merawat serta mengembangkan lahan tersebut jika salah satu anak tidak dapat merawat maka dapat dihibahkan kepada anak satunya yang dapat merawat serta mengembangkan lahan tersebut. (Harlina, 2014). Amanat yang diberikan seorang kepada yang mewaris disebut sebagai wasiat biasanya berupa surat atau secara langsung dikatakan kepada pewaris dengan didampingi kuasa hukum Surat wasiat yang dibuat pewaris bersifat mengikat kepada seorang yang diberikan warisan dan tidak dapat diganggu gugat semasih seorang mampu mengemban tanggung jawab menjaga warisan maka hasilnya dapat dinikmati sendiri jika sebaliknya maka tidak berhak menerima warisan dan menerima resiko tidak mendapatkan warisan.

Seorang dengan kemauannya sendiri memberikan harga bendanya

kepada orang lain namun dengan syarat yang dimilikinya disebut sebagai pewaris Segala yang dikehendaki pewaris bersifat mutlak dan tidak diganggu gugat termasuk tanggung jawab hak dan kewajiban yang nantinya diterima oleh orang yang mewarisi warisan namun tidak semua pewaris memberi syarat ada juga memberikan dengan kewenangan berasa ditangan orang yang mendapat warisan tidak ada tanggung jawab menjaga apa yang diwariskan melainkan sebagai hadiah dari pewaris kepada ahli waris

Segala bentuk peninggalan baik berupa uang tunai lahan tanah perkebunan persawahan yang dimiliki seorang dinamakan warisan Diberikan kepada ahli waris secara terbuka atau diketahui salah keluarga biasanya terdapat surat wasiat saat menerima warisan dengan pesan dari yang memberikan warisan tidak semua ahli waris mendapat hak sepenuhnya terhadap harta warisan namun terdapat tanggung jawab untuk menjaga dan mengembangkan warisan yang dididapat sesuai keinginan pewaris. Warisan adalah suatu peninggalan harta kekayaan kepada ahli waris (Wahyuni, 2018). 
Pewaris biasanya menulis surat wasiat sebagai pesan terakhir yang disampaikan untuk seorang yang diberikan warisan dan dititipkan pada kuasa hukum yang nanti menyampaikan kepada yang menerima warisan saat pewaris meninggal dunia Kuasa hukumlah yang bertugas memantau harta warisan yang ditinggalkan pewaris kepada ahli waris agar tidak disalahgunakan dan sesuai dengan kehendak pewaris yang diutarakan melalui surat wasiat sebagai pesan terakhir Kuasa hukum juga bertugas membuat peralihan hak dari pemegang hak sebelumnya yaitu pewaris kepada orang yang menerima warisan disebut ahli waris. Penelitian ini bertujuan untuk mengkapi pembagian harta warisan secara benar berdasarkan KUHP, dan untuk memahami penyelesaian persoalan warisan terhadap ahli waris.

\section{METODE PENELITIAN}

Penelitian ini menggunakan normatif berpatokan pada peraturan pemerintah yang berfokus dokumen sebagai objeknya dan analisis dalam Informasi yang didapat secara konseptual berkaitan dengan Penelitian hukum normatif adalah hukum kepustakaan yang mengacu pada norma hukum yang terdapat dalam peraturan Perundang-undangan (Waluyo, 2002). Peneliti dalam menyelesaikan penelitian ini dengan tidak menyimpang dari hukum positif dan Penelitian melalui permasalahan yang dipaparkan di atas. Pendekatan perundangan- undangan adalah melakukan suatu penelitian dengan berpatokan pada undang-undang sebagai dasar peneliti. Pendekatan kasus dilakukan guna melihat mencatat dan memahami permasalahan yang diangkat dalam skripsi ini dengan tidak keluar dari zona hukum positif. metode normatif dan kualitatis dimana dalam pengerjaannya penulis menlaah isu hukum dengan didasari peraturan - peraturan hukum Perdata di Indonesia (Ahmad, 2008).

\section{HASIL DAN PEMBAHASAN}

Arti dari hukum waris sendiri ialah suatu peraturan yang mengatur mengenai prosedur perpindahan hak dari generasi sebelumnya ke generasi selanjutnya Peraturan yang membahas tentang suatu peninggalan yang ditinggalkan oleh pemilik sebelumnya karena meninggal dunia dan berupa kekayaan serta memunculkan suatu perpindahan hak milik ke orang yang di percayakan oleh pemilik sebelumnya ialah pengertian dari hukum waris biasanya berdasarkan hubungan keluarga dari pemilik sebelumnya ataupun pihak ketiga Akan tetapi banyaknya pengertian dari hukum waris membuat para ahli sependapat jika hukum waris ialah peraturan yang mengatur cara dan proses perpindahan kekayaan dari pewaris kepada ahli waris atau para ahli warisannya

Dalam peraturan hukum perdata terdapat aturan mengenai hukum keluarga sedangkan hukum waris sendiri ialah salah satu bagian dari hukum keluarga maka dengan ini mengartikan bahwa hukum waris mempunyai kaitan yang erat dengan lingkungan kehidupan keluarga dimana anggotanya ialah manusia karena setiap manusia akan mengalami peristiwa alam yang dinamakan kematian Setiap seseorang yang telah meninggal pasti memiliki seseorang yang menjadi perpindahan kekayaannya Kematian yang tidak dapat di ketahui menyebabkan kemunculan suatu akibat hukum yakni tentang tata cara perpindahan hak dan kewajiban seseorang yang telah meninggal dimana diatur dalam hukum waris Para ahli hukum yang berada di Indonesia masih belum mendapatkan titik untuk menyepakati mengenai pengertian hukum waris sendiri sehingga menyebabkan pengertian hukum waris masih sangat beraneka ragam di Indonesia

Suatu perkara yang dihitung sangat penting ialah mengenai warisan karena menyangkut dari generasi sebelumnya ke generasi selanjutnya Warisan yang dikatakan penting ini seringkali menyebabkan berbagai masalah sehingga seringkali dalam hubungan keluarga rasa kekeluargaan bias terputus karena warisan ini karena adanya perbedaan pendapat mengenai kesepakatan pembagian warisan. Berikut Unsur-unsur dalam hukum waris:

1. Pewarisan yaitu Seseorang yang memiliki kekayaan dimana saat ia telah meninggal dunia menyebabkan suatu persoalan yakni kemana kekayaan yang ia miliki akan di limpahkan

2. Ahli waris yaitu Seseorang atau lebih dari dua orang yang akan menerima hak kekayaan si pewaris apabila telah tiba waktu pewaris meninggal dunia Yang biasanya berdasarkan adanya ikatan hubungan darah 
3. Harta Warisan yaitu Suatu wujud kekayaan yang menjadi persoalan apabila pewaris sudah tiada dan akan di pindah hak kepada ahli waris

Suatu surat wasiat merupakan pernyataan dari pewaris tentang segala sesuatu yang ia kehendaki apabila sudah meninggal yang dibuat dalam bentuk surat Biasanya di keluarkan oleh dari satu pihak dan memuat mengenai waktu kapan diserahkan dan kepada siapanya. Pasal $874 \mathrm{KUH}$ Perdata yang menerangkan tentang arti wasiat atau testament memang sudah mengandung suatu syarat bahwa si pernyataan itu tidak boleh bertentangan dengan undang-undang. Hak yang memiliki segala peninggalan pewaris ialah ahli waris karena sudah diatur sebagaimana mestinya saat ia menjadi sebagai ahli waris apabila an kepada seseorang yang menguasai harta kekayaan tersebut

Apabila dilihat dalam suatu hubungan dengan pewaris sebagai contoh menyewa Maka penuntutan itu tidak dapat dilaksanakan atas harta yang ditinggalkan sebagai peninggalan yang tidak terurus Hak penuntutan tersebut dapat dipergunakan oleh si ahli waris hanya dengan mengajukan gugatannya jika ia meminta haknya dan menyatakan bahwa ia adalah sebagai hak (Suparman, 2007). Karena dalam asas orang perorangan bahwa yang dapat diakui mendapat waris ialah setiap orang bahkan bayi yang baru lahir sekalipun (Darmabrata, 2003). Karena dalam peraturan Undangundang telah memuat penetapan orang yang berbuat tidak patut menerima warisan ialah orang yang telah atau sedang menjalani hukuman dari putusan hakim akibat telah berbuat melawan hukum yakni membunuh dan mencoba membunuh si pewaris Selain itu bagi ahli waris yang telah bertindak menggelapkan dan merubah surat wasiat dengan kasar ataupun dengan ancaman kepada si pewaris Peraturan telah menetapkan juga bahwa orang-orang yang memiliki hubungan dengan karirnya si pewaris juga tidak di ijinkan untuk mendapatkan warisan dari dalam surat wasiatnya yang dimaksud ialah pejabat yang memiliki wewenang yakni notaris dalam pembuatan surat wasiat beserta saksi yang telah di hadirkan dalam pembuatan atau kesepakatan surat wasiat tersebut juga warisan yang diberi wasiat kepada orang yang menjadi perantara dapat dibatalkan yang dimaksud dalam perantara tersebut ialah anak atau istri yang dari orang tidak diperbolehkan menerima warisan yang telah termuat dalam surat wasiat tersebut

Penyelesaian perkara yang paling diminati saat ini penyelesaian diluar pengadilan atau non litigasi Segala suatu yang hemat biaya tanpa perlu melakukan banyak sidang pasti diminati masyarakat yang bersangkutan. Proses penyelesaian tidak memakan banyak waktu dan jika mendapat titik terang tidak perlu melakukan sidang karena permasalahan terselesaikan dengan cepat Kesepakatan antara para pihak yang bersangkutan diluar pengadilan menghasilkan suatu etikat baik karena masing-masing pihak tidak perlu mengeluarkan biaya banyak namun permasalahan sudah selesai dan diakui kedua belah pihak

\section{SIMPULAN DAN SARAN}

\section{Simpulan}

Berdasarkan analisis data peneliti dapat memberikan kesimpulan sebagai berikut:

a. Di dalam suatu pembagian warisan ada yang menurut undang-undang dan menurut suatu wasiat Dimana yang merupakan pembagian menurut undang-undang karena dalam pewarisan perpindahan hak dan kewajiban ahli waris Menurut bentuknya ada tiga macam testament pembagian harta warisan yaitu 1 Openbaartestament suatu terstament dibuat oleh seorang notaris Orang yang akan meninggalkan warisan menghadap pada notaris dan menyatakan kehendaknya 2 Olographis testament harus dituliskan dengan tangan orang yang akan meninggalkan warisan itu sendiri (elgenhading) (gedepoecerd) 3 Testament rahasia juga dibuat sendiri oleh orang yang akan meninggalkan warisan tetapi tidak diharuskan ia menulis dengan tangan sendiri

b. Cara penyelewsaian sengketa non litigasi dan litigasi Penyelesaian masalah di luar pengadilan jalur non litigasi ini dkenal dengan penyelesaian sengketa alternatif juga diartikan sebagai penyelesaian sengketa di luar pengadilan Pada umumnya dinamakan ADR (Alternative Dispute Relosolution) Penyelesaian perkara di luar pengadilan diakui dalam peraturan di Indonesia dalam penjelasan Pasal 3 UU Nomor 14 Tahun 1970 tentang Penyelesaian Perkara di Luar Pengadilan Sedangkan penyelesaian litigasi itu adalah penyelesaian sengketa antara para pihak yang dilakukan di muka pengadilan lembaga penyelesaian sengketa litigasi ada dua yaitu Pengadilan umum pengadilan negeri berwenang memeriksa sengketa sedangkan pengadilan niaga pengadilan khusus yang berada di lingkungan pengadilan umum yang mempunyai 
kompetensi untuk memeriksa dan memutuskan permohonan penyertaan dan penundaan kewajiban pembayaran utang (PKPU) dan sengketa HaKI

\section{Saran}

Ada beberapa saran yang bias peneliti berikan sebagai berikut:

1. Kepada pemerintah sebaiknya lebih turun tangan tentang kasus ini dan memberi tanggapan dan dikeluarkan perlindungan untuk keluarga yang haknya di ambil alih oleh yang seharusnya tidak mempunyai hak dalam warisan tersebut atau pembagiannya yang tidak memihak pihak manapun dan dari golongan apapun dan lebih menegaskan UU tentang perlindungan Ahli waris

2. Kepada masyarakat para pencari keadilan agar dalam penyelesaian sengketa waris diharapkan untuk menyelesaikannya di Pengadilan Dan jika harta warisan hanya dibagi diluar Pengadilan/damai haruslah sesuai dengan hukum yang berlaku karena sebaik-baik hukum tetap yang paling baik hukum yang mempunyai nilai-nilai keadilan yang hakiki.

\section{DAFTAR PUSTAKA}

Ahmad, B. (2008). Metode Penelitian Hukum. Pustakasetia.

Ali, A. (2000). Hukum Warisan kekeluargaan Hukum Pembuktian. Rineka Cipta.

Darmabrata, W. (2003). Hukum Perdata Asas-Asas Hukum Warisan. Universitas Indonesia.

Harlina, Y. (2014). Status Nasab Anak Dari Berbagai Latar Belakang Kelahiran (Ditinjau Menurut Hukum Islam). Hukum Islam, 14(1), 64-81

Oemar Moechthar. (2017). Kedudukan Negara sebagai Pengelola Warisan atas Harta Peninggalan tak Terurus Menurut Sistem Waris Burgerlijk Wetboek. Yuridika, 32(2), 280-309

Ramli, M. (2013). Peranan Advokat dalam Mewujudkan Kewenangan Pengadilan Agama dalam Bidang Kewarisan. Ulumuna, 5(2), 147-16.

Suparman, E. (2007). Hukum Warisan Indonesia. Retika Aditama

Wahyuni, A. (2018). Sistem Waris dalam Perspektif Islam dan Peraturan Perundangundangan Di Indonesia. SALAM: Jurnal Sosial Dan Budaya Syar-I, 5(2), 147-160.

Waluyo, B. (2002). Penelitian Hukum Praktek. Sinar Grafika. 